\title{
THE FIDUCIARY EXPLANATION FOR PRESUMED UNDUE INFLUENCE
}

\author{
MARSHALL HAUGHEY*
}

Despite centuries of the common law more or less recognizing the distinction between actual and presumed undue influence, recent cases from the House of Lords and Supreme Court of Canada indicate a failure to appreciate the true nature of presumed undue influence and its connection to fiduciary law. As such, an appropriate legal test for presumed undue influence is still required. Through an examination and critique of leading case law and academia on the conventional fiduciary obligation, deferential trust, and the two types of undue influence, this article makes a case for the adoption of fiduciary influence as the appropriate test for deferential trust. The circumstances that can give rise to fiduciary influence are infinitely variable; however, courts must determine whether, on the facts, the trusted party acquired influence for the limited and defined purpose of acting in the trusting party's interest at the time of the impugned transaction.
Malgré le fait que pendant des siècles la commonlaw a plus ou moins fait la distinction entre influence indue réelle et présomption d'influence indue, de récentes causes de la Chambre des Lords et de la Cour suprême du Canada indiquent un manque d'appréciation de la véritable nature de présomption d'influence indue et son lien avec la loi fiduciaire. Un test légal indiqué pour présomption d'influence indue est d'ailleurs encore requis. C'est par l'examen et la critique de jurisprudence principale et du monde universitaire sur l'obligation fiduciaire traditionnelle, de fiducie de déférence et les deux genres d'influence indue que cet article fait valoir les mérites de l'adoption de l'influence fiduciaire comme tant le test indiqué pour la fiducie de déférence. Les circonstances de l'influence fiduciaire sont infiniment variables; cependant, les tribunaux peuvent déterminer si, sur la foi des faits, la partie de confiance a acquis l'influence pour les besoins limités et définis d'agir dans l'intérêt de la partie persuadée au moment de la transaction contestée.

\section{TABLE OF CONTENTS}

I. INTRODUCTION . . . . . . . . . . . . . . . . . . . . . . 130

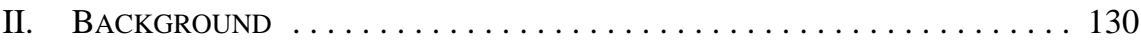

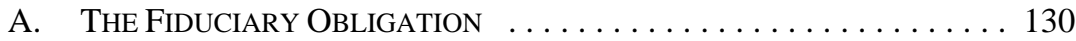

B. Deferential Trust vs Vigilant Trust . . . . . . . . . . . . 132

III. Undue Influence: A TALE of TWO DOCTRINES $\ldots \ldots \ldots \ldots \ldots \ldots \ldots$

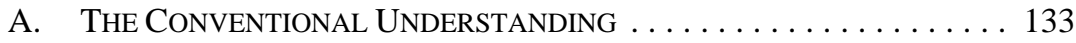

B. The Separate Functions of ACtuAl AND

Presumed Undue InfLUENCE $\ldots \ldots \ldots \ldots \ldots \ldots \ldots \ldots$

IV. RECENT JUdicial TREATMENT OF PRESUMEd UNDUE INFLUENCE $\ldots \ldots 137$

A. The Conventional Understanding . . . . . . . . . . . 137

B. Trouble Begins . . . . . . . . . . . . . . . . . 139

C. Presumed Undue Influence in CanAda . . . . . . . . . . . . 140

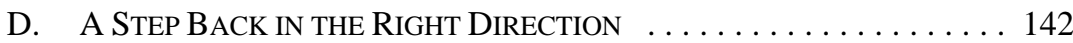

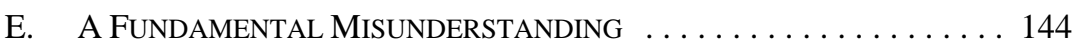

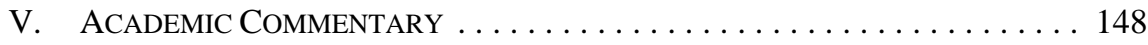

A. Academic Treatment of the Fiduciary ConNection . . . . . 148

B. AdDRESSING ARgUMENTS AGAinst THE FIDUCIARY CONCEPTION $\ldots \ldots \ldots \ldots \ldots \ldots \ldots$

BComm (Saskatchewan), JD (Saskatchewan), Student-At-Law, Bennett Jones LLP, Calgary, Alberta. The author would like to thank the anonymous referees of a previous draft of this article for their valuable feedback and criticism. Any remaining errors or omissions remain the author's. 


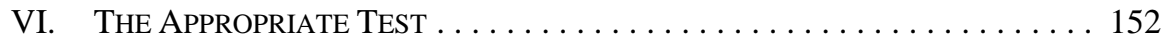

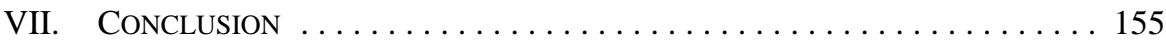

\section{INTRODUCTION}

Recent undue influence jurisprudence is plagued with conceptual misunderstanding. At play are two distinct doctrines: (1) “actual” undue influence; and (2) "presumed” undue influence. Each serves a distinct purpose. Actual undue influence is concerned with coercive or deceptive behaviour, regardless of the context. Presumed undue influence is a manifestation of fiduciary regulation applied in specific circumstances: instances of deferential trust.

For the past few centuries, the common law more or less recognized this difference (at least implicitly) and the rules were structured accordingly. However, beginning with the House of Lords decision in National Westminster Bank Plc. v. Morgan ${ }^{1}$ and culminating in its decision in Royal Bank of Scotland Plc. v. Etridge (No. 2), ${ }^{2}$ the law lords have failed to comprehend the doctrinal interplay.

In Canada, the ship has not strayed quite so far off course. The leading Supreme Court of Canada case recognizes the distinction, at least superficially. ${ }^{3}$ However, upon examination, it does not appear that there is an appreciation of the true nature of presumed undue influence and its connection to fiduciary law. Accordingly, an appropriate legal test for presumed undue influence remains elusive.

In this article, I demonstrate that a test of "influence” properly uncovers arrangements of reposed trust and confidence. I begin by providing a brief overview of the conventional fiduciary obligation and of deferential trust. Then, in more detail, I outline the separate functions and boundaries of the two types of undue influence. Using this conceptual framework, I survey and critique the leading case law and academia. I conclude by making the case for the adoption of a test of fiduciary influence.

\section{BACKGROUND}

\section{A. THE FidUCIARY OBLIgATION}

The purpose of this article is not to debate the theory underlying the fiduciary obligation. Rather, I am relying on the conception formulated by Professor Robert Flannigan, as I find it is cogent, rooted in jurisprudence, and most importantly, based on sound principle. ${ }^{4}$ As will

[1985] UKHL 2, [1985] 1 AC 686 [Morgan].

[2001] UKHL 44, [2002] 2 AC 773 [Etridge].

See Geffen v Goodman Estate, [1991] 2 SCR 353, Wilson J [Geffen].

See Robert Flannigan, “The Fiduciary Obligation” (1989) 9:3 Oxford J Legal Stud 285 [Flannigan, "Obligation”]; Robert Flannigan, "The Boundaries of Fiduciary Accountability” (2004) 83:1 Can Bar Rev 35 [Flannigan, "Boundaries”]; Robert Flannigan, "The Core Nature of Fiduciary Accountability” [2009] NZL Rev 375 [Flannigan, “Core Nature”]; Robert Flannigan, "The Strict Character of Fiduciary Liability” [2006] NZL Rev 209 [Flannigan, “Strict Character”]; Robert Flannigan, "Fact-Based Fiduciary Accountability in Canada” (2010) 36:4 Advocates’ Q 431 [Flannigan, “Fact-Based”]; Robert Flannigan, "Fiduciary Duties of Shareholders and Directors" [2004] J Bus L 277; Robert Flannigan, "The Adulteration of Fiduciary Doctrine in Corporate Law" (2006) 122 Law Q Rev 449; Robert Flannigan, "The [Fiduciary] Duty of Fidelity” (2008) 124 Law Q Rev 274; Robert Flannigan, "Fiduciary 
become evident, Flannigan's fiduciary theory is perfectly harmonious with that of presumed undue influence.

The traditional function of fiduciary regulation is "to control opportunism in limited access arrangements. A monolithic social consensus supports this form of legal discipline."5 The doctrine was erected in response to the innate human tendency to exploit others' trust for one's own gain. It exists solely to ensure loyal service by those who undertake to act in another's interest.

The limited access abstraction developed by Flannigan serves as both the boundary and the test for fiduciary arrangements. A limited access arrangement entails a situation where an actor gains access to the asset array of another, and the former is tasked with producing value for the latter. ${ }^{6}$ Such arrangements are common in our society and include: a lawyer gaining access to a client's confidential information (asset) in order to best represent the client; a mutual fund manager gaining access to an investor's capital (asset) in order to invest for the investor's benefit; and a doctor gaining access to a patient's body and confidential information (assets) in order to diagnose and treat the patient. The common feature present in all of these arrangements is that the access is given for the sole purpose of acting in the interests of the beneficiary. This is not to say the fiduciary cannot benefit from acting in a fiduciary capacity; the fiduciary will often charge a fee for their service. This is acceptable, as it is authorized. In this way, fiduciaries act in their own interest by undertaking to act in the interests of others.

Once an actor enters a limited access arrangement, the fiduciary obligation attaches. The obligation imposed is straightforward: the duty is a general proscription on unauthorized conflicts or benefits. ${ }^{7}$ If the fiduciary acts in contravention of the conflict or benefit rules then he or she is liable. However, detection of a breach may be difficult, as fiduciaries are often sophisticated and may "construct plausible explanations after the fact." ${ }^{8}$ The law must be responsive to this risk; thus, the proscription entails strict liability, which means the only defence is either ex ante or ex post informed consent. ${ }^{9}$ The fiduciary's liability for breach is independent of whether or not the beneficiary suffered harm; all that matters is that the fiduciary received a benefit. ${ }^{10}$ As well, the fiduciary's motive or "state of mind" are irrelevant considerations. ${ }^{11}$ The strictness of the rule is prudent because the lower risk of detection requires a higher deterrence factor. ${ }^{12}$

Mechanics” (2008) 14 CLELJ 25; Robert Flannigan, “Director Duties: A Fiduciary Duty to Confess?” (2005) 26:11 Bus L Rev 258; Robert Flannigan, "The Fiduciary Accountability of Ordinary Employees," Case Comment on Imperial Sheet Metal Ltd v Landry, (2007) 13 CLELJ 283; Robert Flannigan, “Fiduciary Accountability Transformed” (2009) 35:3 Advocates’ Q 334; Robert Flannigan, “A Romantic Conception of Fiduciary Obligation,” Book Review of Fiduciary Law by Leonard Rotman, (2005) 84:2 Can Bar Rev 391; Robert Flannigan, “The Fiduciary Duty of Departing Employees” (2009) 14 CLELJ 335; Robert Flannigan, "Child Labour: The Partial Fiduciary Accountability of Parents” (2007) 86:2 Can Bar Rev 293; Robert Flannigan, “Access or Expectation: The Test for Fiduciary Accountability” 89:1

Can Bar Rev 1.

Flannigan, "Boundaries,” ibid at 35.

Flannigan, "Core Nature,” supra note 4 at 379.

Ibid at 380.

Flannigan, "Strict Character,” supra note 4 at 212.

Ibid.

Boardman v Phipps, [1966] UKHL 2, [1967] 2 AC 46 at 115.

Flannigan, "Core Nature," supra note 4 at 381.

Flannigan, "Strict Character," supra note 4 at 212. 
Limited access arrangements can be either status-based or fact-based. Status categories include the familiar lawyer/client, doctor/patient, trustee/beneficiary, and guardian/ward, among others. Fact-based fiduciaries are recognized as such because they meet the test of being in a limited access arrangement. It is important to note that there is nothing substantively different about a status-based or fact-based fiduciary. In both cases, having limited access to another's assets makes one a fiduciary. The status categories exist purely as evidential expediency due to the fact that courts have previously recognized that limited access is always present in those arrangements. In order for there to be fact-based fiduciary accountability, there must be an other-regarding undertaking. ${ }^{13}$ For example, "it is the law of agency that requires agents to perform their agency undertakings in the best interest of their principals [that is, the other-regarding undertaking]. The distinct parallel fiduciary duty of agents is to forgo their self-interest in exploiting the access that accompanies the agency undertaking." 14 The strictness of the rule serves as a prophylaxis. Unlike wider civil law areas (for example, tort, contract, estoppel, or unconscionable dealing) where the paradigm is "repair" for the harm done, the fiduciary rule strives for "prevention."15

Opportunism is a generic mischief in that it occurs across all idiosyncratic nominate legal categories. ${ }^{16}$ Public or private sector, commercial or non-commercial activity, the mischief is unchanging. Due to the generic nature of the mischief, we regulate it in the same manner no matter where we find it. In this way, fiduciary regulation is a narrow jurisdiction that is obsessed with a singular mischief spanning the wide range of human interactions.

\section{B. DEFERENTIAL Trust VS VigiLANT Trust}

The limited access test has limitations in certain contexts. This is not a substantive or conceptual flaw; rather, the concept is sound in that it effectively targets the opportunism mischief. In certain situations, however, it is difficult to determine whether limited access is present. Such a situation is where one actor reposes trust and confidence in another. Flannigan has described this type of trust as "deferential trust": ${ }^{17}$

A person may trust another in an unconstrained and uninhibited personal way. Such trust may arise out of feelings of intimacy or security brought about by the affection or concern of that other. It may arise out of guidance or intercession that has been offered and accepted in the past. This kind of trust may be created over time or may arise immediately because of the knowledge, expertise or office occupied by the trusted person. It is a 'deferential' kind of trust in the sense that the trusting person will defer to the judgment of the trusted person. The deference may be total, or it may be only partial or situational. It is accompanied, in some cases, by elements of necessity, dependence or submission. In other cases there is no demonstrated vulnerability. But the trusted person knows that his or her judgment is being relied on in the circumstances. ${ }^{18}$

$13 \quad$ Flannigan, "Fact-Based," supra note 4 at 439.

Ibid at 440 [emphasis in original].

Rick Bigwood, "From Morgan to Etridge: Tracing the (Dis)Integration of Undue Influence in the United Kingdom" in Jason W Neyers, Richard Bronaugh \& Stephen GA Pitel, eds, Exploring Contract Law (Oxford: Hart Publishing, 2009) 379 at 384 [Bigwood, “Tracing”].

16 Professor Flannigan refers to other discrete areas of the law as "nominate" because they are named (e.g., the law of agency, trust law, corporate law, etc.).

17 The use of the term "trust" here is not referring to the estate planning and business vehicle in which assets are placed and controlled by trustees for the benefit of the beneficiaries. Instead, it refers to the plain meaning of the word, such as where one places their trust in another.

18 Flannigan, “Obligation,” supra note 4 at 286-87. 
Deferential trust may be contrasted with another type of trust that gives rise to a fiduciary obligation. This is known as "vigilant trust":

[This] type of trust is more removed. There is typically no deference or vulnerability involved. It is the kind of trust that employers have in their agents and servants. Employers expect their agents and servants to act faithfully but they do not have unreserved faith in them. They remain wary and, in the extreme, even sceptical of them. Employers are 'vigilant' in the sense of remaining aware. They trust their agents and employees but remain observant for signs that their trust is misplaced. The expectation underlying this kind of trust is that of fair dealing between competent and capable persons. ${ }^{19}$

The mischief to be targeted in either situation is the same. The trusted party (the fiduciary) is not to act opportunistically by diverting value away from the trusting party (the beneficiary) to himself. However, with deferential trust, the mischief arises in a specific way:

A danger exists in certain relationships where influence naturally flows from the confidence or deferential trust reposed by one person in another. This trust tends to arise, for example, where one person serves as an adviser to another or where one person occupies a position of authority, respect or expertise in relation to another. The danger in these relationships is that the influence may be excessive or undue in the circumstances and may have a mischievous end. A disadvantageous bargain for the trusting party may be the result. $^{20}$

The limited access test is appropriate for identifying fiduciary relationships where there is vigilant trust. However, as Flannigan recognizes, "the presence of 'access' to assets is not, for cases of deferential trust, a sufficient test." ${ }^{21}$ This is because in cases of deferential trust, it "appears to others that the trusting party alone is acting and so alone has access." 22 In this sense, the access is "masked." 23

To combat the problem of concealed access, the law relieves the beneficiary of the fiduciary arrangement from affirmative proof: "[U]ndue influence often has a subtle operation and may be undetected or unprovable as a result. Accordingly, because of the detection and evidentiary difficulties, the law presumes undue influence if a 'special' relationship exists. This special relationship corresponds to the relationship where a person reposes a deferential trust in another."24

\section{UNDUE INFLUENCE: A TALE OF TWO DOCTRINES}

\section{A. The Conventional Understanding}

Undue influence is a creation of equity under which a transaction may be set aside because undue influence has either actually infected or is presumed to have infected the sufficiency of a party's consent. ${ }^{25}$ It was developed "not to save people from the consequences of their

Ibid at 287 [footnote omitted].

Ibid at 292.

Ibid at 309.

Ibid.

Ibid.

Ibid at 293 [footnote omitted].

CED (West 4th), vol 14, title 34 at $§ 532$. 
own folly but to save them from being victimized by other people.”26 The doctrine can be traced back at least as far as the 1807 case of Huguenin v. Baseley. ${ }^{27}$ It comes into play in two ways, as explained by Lord Justice Lindley in the seminal case of Allcard v. Skinner:

First, there are the cases in which there has been some unfair and improper conduct, some coercion from outside, some overreaching, some form of cheating, and generally, though not always, some personal advantage obtained by a donee placed in some close and confidential relation to the donor....

The second group consists of cases in which the position of the donor to the donee has been such that it has been the duty of the donee to advise the donor, or even to manage his property for him. ${ }^{28}$

The first class of cases referred to by Lord Justice Lindley can be characterized as cases of actual undue influence. The second class of cases can be described as cases of presumed undue influence. Regarding the latter, where there is reposed trust and confidence in the trusted party and there is an impugned transaction where the trusted party receives a benefit, there is a rebuttable presumption that the trusting party was unduly influenced. In defence, the trusted party may adduce evidence to show that the trusting party was fully informed and freely entered into the transaction. Where there is no reposed trust and confidence in the trusted party, the onus is on the claimant to affirmatively prove actual undue influence.

\section{B. The SeParate Functions of Actual and Presumed Undue Influence}

Actual and presumed undue influence serve two different purposes. Paul Finn notes that it is "[m]ore for historical reasons than for reasons of sound principle [that actual and presumed undue influence] ... are commonly regarded as constituting a separate body of doctrine falling under the designation 'undue influence." 29 Actual undue influence is concerned with "conduct that [is] straightforwardly coercive, exploitative, manipulative or deceptive toward a peculiarly vulnerable party. Such conduct [is] unacceptable for that reason simpliciter." ${ }^{30}$ Rick Bigwood writes that actual undue influence is equity's counterpart to the common law's duress doctrine and it is "closely related to, if not merely a manifestation of,"31 equity's unconscionable dealing. Actual undue influence is not reliant on any sort of fiduciary relationship. Instead, equity's intervention is based on the principle that "no one shall be allowed to retain any benefit arising from his own fraud or wrongful act," 32 regardless of the arrangement.

Presumed undue influence has an entirely different concern. Where the trusting party reposes trust and confidence (deferential trust) in a trusted party, they are giving that trusted party access to their decision-making faculties (asset) ${ }^{33}$ for the defined and limited purpose of acting in their interest. Thus, a limited access arrangement occurs. The result is that the

Geffen, supra note 3 at 368. See also Allcard v Skinner (1887), 36 Ch D 145 at 182 (CA) [Allcard]. (1807), 33 ER 526.

Allcard, supra note 26 at 181. Lord Justice Cotton also noted this distinction in his judgment (ibid at 171).

PD Finn, “The Fiduciary Principle” in TG Youdan, ed, Equity, Fiduciaries and Trusts (Toronto: Carswell, 1989) 1 at 43 [Finn, "Fiduciary Principle”].

Bigwood, "Tracing," supra note 15 at 380 [emphasis in original].

Ibid.

Allcard, supra note 26 at 171.

A person's decision-making faculties can be characterized as an asset, as they can be exploited for gain. 
trusted party is a fiduciary, at least to the extent of the scope of the limited access. Therefore, the trusted party is prohibited from deriving an unauthorized benefit from that arrangement.

The rationale for this outcome is based upon the fundamental social norm of opportunism regulation. It is the unambiguous and universally supported guiding principle that underlies the fiduciary obligation. Once it is appreciated that opportunism regulation in limited access arrangements is the governing policy, the boundaries of presumed undue influence can be deciphered.

Opportunism regulation, generally, is the overarching social norm that underlies both actual and presumed undue influence. However, actual and presumed undue influence are targeted at two different types of opportunistic mischief: "production" opportunism and "exchange" opportunism, respectfully. ${ }^{34}$ Production opportunism is where one acquires access to another's assets in order to serve the interests of that other, but then exploits that access for unauthorized personal gain. Fiduciary regulation is designed to combat production opportunism by requiring trusted parties to forego unauthorized conflicts or benefits in limited access arrangements.

Exchange opportunism "is the opportunism that operates at the exchange interface between [parties].”35 Exchange opportunism is, for the most part, acceptable because we recognize that when two parties are negotiating, they are acting in their own self-interest. Parties act opportunistically by trying to secure the best possible terms on an exchange. Flannigan notes that "[w]e do not regulate exchange opportunism because exchanges, by their nature, involve parties who are looking exclusively to their own self-interest. Actors may, as their part of the exchange, give their undertaking to act for another, but the immediate exchange process is purely self-interested on both sides." ${ }^{36}$ Exchange opportunism is a different beast than production opportunism. Presumed and actual undue influence are aimed at two different mischiefs and are, therefore, doctrinally distinct.

The interplay between undue influence and fiduciary law is represented diagrammatically in Figure 1. According to Figure 1, although both actual and presumed undue influence fall within the sphere of undue influence generally, presumed undue influence is wholly within the scope of fiduciary law and doctrinally separate from actual undue influence. Thus, presumed undue influence can be fully explained by appealing to fiduciary principles. One will also note that the boundaries of fiduciary obligation are broader than those of presumed undue influence. This is because limited access arrangements can occur where there is no reposed trust or confidence (which are instances of vigilant trust). ${ }^{37}$ That is, limited access

See Robert Flannigan, “Commercial Fiduciary Obligation” (1998) 36:4 Alta L Rev 905 [Flannigan, "Commerical”].

Ibid at 914.

Ibid at 915. Though it may not be quite accurate to say that exchange opportunism is completely unregulated (actual undue influence, duress, and unconscionable dealing are all designed to limit the ability of parties to act opportunistically in arm's length transactions), it is correct that fiduciary regulation is unconcerned with it.

Ibid at 906 . Flannigan criticizes characterizing fiduciary relationships generally as being concerned with abuses of trust or confidence. He states that this description is too narrow because it implies that the absence of an actual trusting relationship is fatal to the existence of fiduciary status, when actual subjective trust is not required. He also finds the phrase vague and posits that more specific analytical propositions are required (ibid). 
is the boundary for fiduciary accountability, ${ }^{38}$ while reposed trust and confidence (deferential trust) is the boundary of presumed undue influence.

\section{Figure 1}

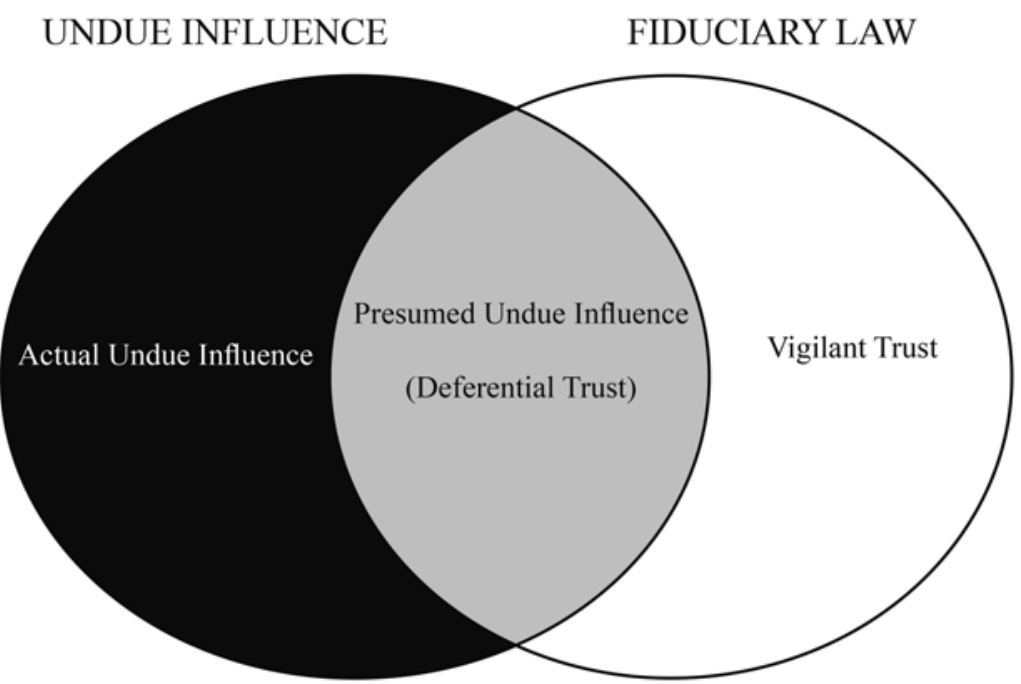

There are those who may not agree with this formulation. Mindy Chen-Wishart, for example, sees the distinction as one between acts (actual undue influence) and omissions (presumed undue influence). ${ }^{39}$ She reasons that " $[b]$ oth are manifestations of the essence of undue influence; namely, the defendant's failure to safeguard the claimant's interests in view of their relationship. Both represent the implicit norms of the relationship of influence." ${ }^{\prime 0}$ She concludes that actual and presumed undue influence are "merely points on a spectrum." ${ }^{41}$ However, it is doubtful that this view would withstand scrutiny. While it is true that a defendant must act to procure actual undue influence, there is no reason why a trusted party's acts cannot constitute presumed undue influence. Presumed undue influence does not come about solely by omissions; a trusted party can actively shape the decisionmaking of the trusting party to unduly benefit the former. ${ }^{42}$ Also, I have shown, and will further demonstrate, that actual and presumed undue influence are aimed at two entirely different types of mischief and have different doctrinal underpinnings. Characterizing them

Mindy Chen-Wishart, "Undue Influence: Beyond Impaired Consent and Wrongdoing towards a Relational Analysis" in Andrew Burrows \& Lord Rodger of Earlsferry, eds, Mapping the Law: Essays in Memory of Peter Birks (Oxford: Oxford University Press, 2006) 201 at 218-19 [Chen-Wishart, "Impaired Consent"].

$40 \quad$ Ibid at 219 [footnote omitted; emphasis in original].

$41 \quad$ Ibid. See also Mindy Chen-Wishart, "Undue Influence: Vindicating Relationships of Influence" (2006) 59:1 Curr Legal Probs 231 at 265.

42 Rick Bigwood, Exploitative Contracts (Oxford: Oxford University Press, 2003) at 375, n 10. Bigwood notes that a trusted party may wrongfully affect the trusting party's will by either active or passive means. 
as merely different points on a spectrum is to misunderstand their distinct fundamental natures.

\section{RECEnt Judicial Treatment OF PREsumed Undue INFLUENCE}

Much like fiduciary law, presumed undue influence has developed from accepted categories such as trustee/beneficiary, solicitor/client, doctor/patient, parent/child, and guardian/ward, among others. ${ }^{43}$ However, it is now generally accepted that "the relationships in which undue influence will be presumed are not confined to fixed categories and that each case must be considered on its own facts." ${ }^{44}$ If it can be established that a "special" relationship exists between the parties and there is an impugned transaction, undue influence will be presumed - though, "what constitutes such a 'special' relationship is a matter of some doubt." 45

\section{A. The ConVentional Understanding}

In Johnson v. Buttress, ${ }^{46} \mathrm{Mr}$. Buttress had made an inter vivos transfer of his main asset, a cottage, to Mrs. Johnson, the woman on whom he relied to take care of him in the latter years of his life. Upon the death of Buttress, the executor of his estate sued to recover the cottage on the basis of undue influence. At trial, Justice Nicholas held that, at the time of the transfer, Johnson had a fiduciary relation to the deceased, who had placed his trust and confidence in her. ${ }^{47}$ This raised the presumption of undue influence, of which there was insufficient evidence to rebut. On appeal, the High Court of Australia confirmed this finding. Justice Dixon explained that "[i]f the circumstances of the transaction are such as to throw upon the donee the burden of justifying it as an independent act resolved upon by a free and understanding mind, the burden could not be discharged unless such a view of the origin and purpose of the transfer were negatived by satisfactory evidence." 48 He also addressed the rule's policy: "The basis of the equitable jurisdiction to set aside an alienation of property on the ground of undue influence is the prevention of an unconscientious use of any special capacity or opportunity that may exist or arise of affecting the alienor's will or freedom of judgment in reference to such a matter." 49 Therefore, despite an absence of facts to suggest mala fides on the part of Johnson, ${ }^{50}$ the fact that she stood in an antecedent relation of influence over Buttress, coupled with an inability to rebut the presumption, meant that the cottage was recovered by the executor.

Justice Dixon opined that in certain “well-known relations” (in other words, status-based arrangements), the presumption would apply. ${ }^{51}$ However, the doctrine was not confined to fixed categories of relations; whenever one occupied a position of ascendancy or influence

Geffen, supra note 3 at 370 , Wilson J.

Ibid. See also Lloyds Bank Ltd v Bundy, [1974] EWCA Civ 8, 3 WLR 501 at 510, Sir Eric Sachs [Bundy].

Geffen, ibid.

[1936] HCA 41, 56 CLR 113 [Buttress].

Ibid at 124.

Ibid at 133.

Ibid at 134 .

The Court declared that the facts were perfectly consistent with there being no undue influence.

Buttress, supra note 46 at 134. 
over another, the doctrine was applicable. ${ }^{52}$ The ascendant party would fall under a duty displaying "fiduciary characteristics." 53 As a result, if a trusted party

has chosen to accept a benefit which may well proceed from an abuse of the authority conceded to him, or the confidence reposed in him; and the relations between him and the donor are so close as to make it difficult to disentangle the inducements which led to the transaction [then] [t]hese considerations combine with reasons of policy to supply a firm foundation for the presumption against a voluntary disposition in his favour. $^{54}$

More recently, in Bundy the issue was whether a guarantor's deferral to a bank manager's judgment gave rise to a "special" relationship. The majority of the English Court of Appeal disposed of the case on the basis of presumed undue influence. ${ }^{55}$

It is worth noting that Sir Eric Sachs phrased the issue as whether or not the bank owed Mr. Bundy a duty of "fiduciary care."56 Sir Eric went on to state that everything depended on the particular facts and that "it is neither feasible nor desirable to attempt closely to define the relationship, or its characteristics, or the demarcation line showing the exact transition point where a relationship that does not entail that duty passes into one that does." ${ }^{57}$ As will be seen, Sir Eric is not alone in his inability to delineate the boundaries of presumed undue influence. Yet, despite the difficulty in discerning presumed undue influence's boundaries, his lordship sought to provide some "elements" that in previous cases led to such a finding.

Sir Eric stated that a special relationship tended to arise in cases "where someone relies on the guidance or advice of another, where the other is aware of that reliance and where the person upon whom reliance is placed obtains, or may well obtain, a benefit from the transaction or has some other interest in it being concluded." ${ }^{58}$ Here, his lordship is stating the conventional position. He described a situation where one had placed deferential trust in a trusted party and a consequent prohibition on the trusted party from obtaining an unauthorized conflict or benefit because of his position.

Sir Eric delved briefly into the policy in support of presumed undue influence. He cited Allcard, where Lord Justice Cotton stated that in cases of presumed undue influence "the Court interferes, not on the ground that any wrongful act has in fact been committed by the [defendant], but on the ground of public policy, and to prevent the relations which existed between the parties and the influence arising therefrom being abused."59 Sir Eric rightly recognized that the principles of "fiduciary care" dictate that no benefit can be retained by the trusting party once the special relationship had been shown to exist unless it is "positively established that the duty of fiduciary care has been entirely fulfilled"60 (that is, the trusting party's free and fully informed consent has been obtained).

Ibid at $134-35$.

Ibid at 135 .

Ibid.

Sir Eric Sachs with Lord Justice Cairns concurring. Lord Denning decided the case on "inequality of bargaining power” (supra note 44 at 508). Lord Denning's decision is not relevant for our purposes. Ibid at 510.

Ibid.

Ibid at 510-11.

Allcard, supra note 26 at 171.

Bundy, supra note 44 at 512. 


\section{B. Trouble Begins}

Presumed undue influence was examined by the House of Lords in Morgan. Lord Scarman was substantially in agreement with Sir Eric's findings of law in Bundy. However, he noted that the principle justifying undue influence was not "a vague 'public policy,," 61 but rather, was aimed specifically at the victimization of one party by the other. He also took issue with Sir Eric's use of words and phrases such as "confidence," "confidentiality," and "fiduciary duty." 62 Lord Scarman opined that "[t]here are plenty of confidential relationships which do not give rise to the presumption of undue influence ... and there are plenty of nonconfidential relationships in which one person relies upon the advice of another, e.g. many contracts for the sale of goods." 63 This assertion explains his aversion to the use of "confidence” and "confidentiality," but he did not elaborate on why references to "fiduciary duty” were inappropriate in the analysis.

Like Sir Eric, Lord Scarman found it difficult to define the boundaries of the doctrine: "There is no precisely defined law setting limits to the equitable jurisdiction of a court to relieve against undue influence. This is the world of doctrine, not of neat and tidy rules."64 However, his lordship dismissed Sir Eric's confidentiality requirement while erecting nothing, other than the vague notion of "dominating influence," in its place. There is nothing concrete to guide the analysis.

In response, critics argue that in these situations, "some idea of where the line lies between relationships which attract the doctrine and those which do not, some criterion of relevant fact, remains important." ${ }^{65}$ Lord Scarman's decision is unhelpful in that it "abandon[s] the doctrine in an unstructured wilderness of fact and circumstance."66 This is likely why Lord Scarman's decision "has met with considerable disfavour in the academic community." 67 Indeed, as Bigwood notes, “[i]n order to achieve adequate conceptual tractability, if not sharp boundaries, it is important that courts erect, and then operate within, coherent intellectual frameworks for approaching, organising, and understanding the distinct factual and doctrinal criteria upon which the law of undue influence rests."

At the English Court of Appeal level in the Morgan case, the two-judge panel held that it was not necessary to show a disadvantageous bargain to establish undue influence. However, Lord Scarman specifically overruled them on this point:

Whatever the legal character of the transaction, the authorities show that it must constitute a disadvantage sufficiently serious to require evidence to rebut the presumption that in the circumstances of the relationship between the parties it was procured by the exercise of undue influence. In my judgment, therefore, the Court of Appeal erred in law in holding that the presumption of undue influence can arise from the evidence of the

Morgan, supra note 1 at 705.

Ibid at 703 .

Ibid.

Ibid at 709.

David Tiplady, “The Limits of Undue Influence” (1985) 48 Mod L Rev 579 at 580.

Ibid.

Geffen, supra note 3 at 371, Wilson J.

Rick Bigwood, "Undue Influence in the House of Lords: Principles and Proof” (2002) 65 Mod L Rev 435 at 435 [Bigwood, "Principles and Proof”]. 
relationship of the parties without also evidence that the transaction itself was wrongful in that it constituted an advantage taken of the person subjected to the influence which, failing proof to the contrary, was explicable only on the basis that undue influence had been exercised to procure it.

The wrongfulness of the transaction must, therefore, be shown: it must be one in which an unfair advantage has been taken of another. ${ }^{69}$

As noted above, in Geffen, Justice Wilson stated that the requirement of a manifest disadvantage had come under heavy criticism. This is not surprising when one realizes that cases of presumed undue influence are actually instances of fiduciary accountability. Fiduciary regulation was erected to control opportunism in limited access arrangements. The doctrine of presumed undue influence is similarly erected to control opportunism in specific types of limited access arrangements: those of deferential trust. Requiring that the plaintiff prove a manifest disadvantage undermines the purpose behind why the doctrine was established.

\section{Presumed Undue Influence in CANAdA}

Geffen is the leading Supreme Court of Canada decision concerning presumed undue influence. In Geffen, Justice Wilson attempted to formulate a cogent legal test for deferential trust. She agreed with Lord Scarman and dismissed Sir Eric’s “confidence” criterion as not accurately capturing the essence of relationships that give rise to the presumption. ${ }^{70}$ She found "reliance" faulty for the same reason. ${ }^{71}$ Instead, Justice Wilson held that the existence of a "dominant relationship” was enough:

It seems to me rather that when one speaks of 'influence' one is really referring to the ability of one person to dominate the will of another, whether through manipulation, coercion, or outright but subtle abuse of power... To dominate the will of another simply means to exercise a persuasive influence over him or her. ${ }^{72}$

She elaborated that "the inquiry should begin with an examination of the relationship between the parties. The first question to be addressed in all cases is whether the potential for domination inheres in the nature of the relationship itself." ${ }^{, 73}$ However, the inquiry should not end there.

Regarding Lord Scarman’s controversial “manifest disadvantage” requirement, Justice Wilson initially held that it limited the doctrine too much. She stated that "[d]isadvantage is ... not a particularly appropriate concept for general application to the wide variety of situations to which the doctrine of undue influence could conceivably apply."74 This was a 
welcome development, as the disadvantage requirement is irrelevant and harmful. However, Justice Wilson would quickly contradict this finding.

Despite the fact that she had already dismissed Lord Scarman's manifest disadvantage requirement, Justice Wilson went on to state that in the case of commercial transactions, "the plaintiff should be obliged to show, in addition to the required relationship between the parties, that the contract worked unfairness either in the sense that he or she was unduly disadvantaged by it or that the defendant was unduly benefited by it."75 She attempted to justify this distinction in the commercial context on the grounds that a court of equity "must accord some degree of deference to the principle of freedom of contract and the inviolability of bargains." 76

Applying fiduciary principles contingently upon whether the context is commercial is inappropriate. ${ }^{77}$ It is similarly unwarranted in the presumed undue influence analysis because the mischief is the same. Flannigan has written that the issue of whether an equitable doctrine is commercially applicable cannot properly be resolved at a broad level: "Instead, each equitable doctrine must be evaluated in terms of the specific function it is intended to serve."78 For presumed undue influence, the function is regulating opportunism in arrangements of deferential trust, and instances of deferential trust are prevalent in both the commercial and non-commercial sectors. Therefore, a distinction at this level must fail.

A sharp boundary is lacking between commercial and non-commercial activity. ${ }^{79}$ However, even if a breaking point were clear, a claim that fiduciary principles are inapplicable in the former is incoherent. When the matter is viewed in terms of the mischief involved, "it is clear that opportunism is a mischief that is independent of the commercial or non-commercial nature of the acquired access. Actors are no less likely to act opportunistically because the setting is a commercial one. Accordingly ... there is no natural ‘commercial' exception.”,

It is apparent that Justice Wilson's comments are problematic. There is no principled reason to require a trusting party to prove a manifest disadvantage in a commercial setting. In further support of her findings she stated: "Moreover, it can be assumed in the vast majority of commercial transactions that parties act in pursuance of their own self-interest." It should be noted that self-interest is not the exclusive domain of commercial activity. A client is acting in a self-interested way when he consults a lawyer, whether it is for a commercial transaction or for criminal defence. In either case, the client has placed his or her trust in the lawyer's advice and should be protected from the lawyer's opportunistic conduct. Also, as noted above, becoming a fiduciary is an inherently self-interested act, in that fiduciaries often charge fees to act in a fiduciary capacity. Arguably, self-interest drives performance of most, if not all, of one's activities. Therefore, Justice Wilson's adoption of

Ibid at 378 .

Ibid.

Flannigan, “Commercial,” supra note 34 at 912.

Ibid.

Ibid.

Ibid.

Geffen, supra note 3 at 355. 
the disadvantage requirement is specious and should be rejected. It clearly has no place within fiduciary law and, therefore, cannot be included in presumed undue influence.

\section{A STEP BACK IN THE RIGHT DIRECTION}

Subsequent to Geffen, the English Court of Appeal formulated a framework for analyzing undue influence in Bank of Credit and Commerce International S.A. v. Aboody, ${ }^{82}$ which was adopted by the House of Lords in Barclays Bank Plc. v. O'Brien. ${ }^{83}$ In O'Brien, Lord BrowneWilkinson explained that undue influence can either be Class 1 (actual) or Class 2 (presumed). Presumed undue influence can be established in one of two ways: either the relationship is a recognized category at law, such as solicitor/client or doctor/patient (Class 2A), or "the complainant proves the de facto existence of a relationship under which the complainant generally reposed trust and confidence in the wrongdoer"84 (Class 2B). It is clear that Class 2A relationships are the status categories. Class 2B, then, is a fact-based inquiry to determine whether reposed trust and confidence (deferential trust) is present. This is precisely the same procedure employed in the fiduciary analysis. ${ }^{85}$

Constructing the analytical framework in this manner shows that Lord Browne-Wilkinson appreciated the separate character of actual and presumed undue influence. He also appreciated the fiduciary nature of presumed undue influence. In CIBC Mortgages Plc. v. $\mathrm{Pitt}^{86}$ the companion case to O'Brien, his lordship questioned whether presumed undue influence and breach of confidence (fiduciary breach) were actually separate doctrines:

I should add that the exact limits of the decision in Morgan may have to be considered in the future. The difficulty is to establish the relationship between the law as laid down in Morgan and the long standing principle laid down in the abuse of confidence cases viz. the law requires those in a fiduciary position who enter into transactions with those to whom they owe fiduciary duties to establish affirmatively that the transaction was a fair one.... The abuse of confidence principle is founded on considerations of general public policy, viz. that in order to protect those to whom fiduciaries owe duties as a class from exploitation by fiduciaries as a class, the law imposes a heavy duty on fiduciaries to show the righteousness of the transactions they enter into with those to whom they owe such duties. This principle is in sharp contrast with the view of this House in Morgan that in cases of presumed undue influence (a) the law is not based on considerations of public policy and (b) that it is for the claimant to prove that the transaction was disadvantageous rather than for the fiduciary to prove that it was not disadvantageous. Unfortunately, the attention of this House in Morgan was not drawn to the abuse of confidence cases and therefore the interaction between the two principles (if indeed they are two separate principles) remains obscure. ${ }^{87}$

Unfortunately, as we will later see, the House of Lord's next opportunity to further investigate these issues was squandered in Etridge. ${ }^{88}$

(1988), [1990] 1 QB 923 (CA) [Aboody].

[1993] UKHL 6, [1994] 1 AC 180 [O’Brien].

Ibid at 189.

See Flannigan, "Fact-Based,” supra note 4.

[1993] UKHL 7, [1994] 1 AC 200 [Pitt].

Ibid at 209 [emphasis in original].

Karen Scott, “Taking the ‘Undue' Out of Presumed Undue Influence,” Case Comment on Hammond v Osborn, [2003] LMCLQ 145 at 149: “The relationship between wider fiduciary principles, where the fiduciary has to justify the transaction, and the presumption of undue influence, where the fiduciary has to refrain from wrongdoing, was undeniably insufficiently explored in Etridge (No. 2).” 
The O'Brien framework was adopted by the Ontario Court of Appeal in Bank of Montreal $v$. Duguid. ${ }^{89}$ The issue in Duguid was whether a presumption of undue influence was appropriate between a husband and wife. In that case, Associate Chief Justice Osborne adopted the $O$ 'Brien framework and found it to be substantially the same as Justice Wilson's approach in Geffen. However, upon examination, this synthesis might have been premature. While Lord Browne-Wilkinson specifically used the phrase "reposed trust and confidence" for Class 2B (fact-based) relationships, it appears that Justice Wilson did not believe reposed trust and confidence was enough to found the presumption. Justice Wilson's test consisted of establishing a dominant relationship which, to her, was not the equivalent of reposed trust and confidence: "The ability to exercise such influence [that is, a dominance relationship] may arise from a relationship of trust or confidence but it may arise from other relationships as well."90 This statement makes clear that Justice Wilson viewed a dominant relationship to be broader than a relationship of reposed trust and confidence. Therefore, it was incorrect to say that Justice Wilson and Lord Brown-Wilkinson's tests were substantially the same, since Justice Wilson did not accept reposed trust and confidence as the test.

Moreover, Justice Wilson's judgment did not seem to respect the fiduciary nature of presumed undue influence. As she stated: "The point is that there is nothing per se reprehensible about persons in a relationship of trust or confidence exerting influence, even undue influence, over their beneficiaries. It depends on their motivation and the objective they seek to achieve thereby." 91 This perplexing passage is obviously flawed. How can it ever be acceptable for a person in a relationship of trust or confidence (a fiduciary) to exert undue influence over their beneficiaries? ${ }^{92}$ Justice Wilson found that undue influence was acceptable in relationships of reposed trust and confidence, as long as the trusted party's motivations and objectives were proper. This was a disturbing finding because it deviated, without justification, from a long line of authorities which have used reposed trust and confidence as the legal test for presumed undue influence. Perhaps even more problematic is that it opened the door for an investigation into the subjective motivations and objectives of the trusted party.

We know that fiduciary accountability is a strict liability regulation. ${ }^{93}$ As a subset of fiduciary law, presumed undue influence necessarily entails a strict character. This means the only defence is informed consent by the trusting party (beneficiary). Therefore, it is clear that Justice Wilson's comments regarding the trusted party's objectives and motivations are worrisome. If the liability for undue influence were not strict, trusted parties could avoid liability by shaping their own transactions to replicate or mirror the accepted transactions. ${ }^{94}$

Flannigan has noted that the detection of opportunism is most difficult in the case of sophisticated fiduciaries. ${ }^{95}$ Many trusted parties such as doctors, lawyers, and accountants are sophisticated in their operations. These sophisticated actors are easily able to mask or conceal a nefarious intent under the guise of acting in the beneficiary's interest: “ $\mathrm{A}$ strict

(2000), 47 OR (3d) 737 (CA) [Duguid].

Geffen, supra note 3 at 377 [emphasis added].

Ibid.

Understandably, Justice La Forest distanced himself from Justice Wilson's remarks here: ibid at 394.

Flannigan, "Strict Character," supra note 4 at 212.

Ibid at 211.

Ibid at 212. 
ethic is calculated to negate the manipulations of those best able to conceal their corruption." ${ }^{, 96}$ It follows then, that the lower the risk of detection, the higher the need for a deterrence regulation. ${ }^{97}$ It is clear that judges need not delve into the motivations behind a trusted party's decision. Instead, the mere existence of an unauthorized conflict or benefit is enough to have the transaction set aside.

The deficiencies in Justice Wilson's analysis in Geffen are apparent. These issues stem from a conceptual misunderstanding of the nature of presumed undue influence. It is understandable why in Duguid, Assistant Chief Justice Osborne found the Geffen and O'Brien decisions to be congruent. By doing so, the Court could adopt the superior O'Brien analysis, which respected the fiduciary nature of presumed undue influence, rather than follow a confused understanding in Geffen, to which it was bound.

\section{E. A Fundamental Misunderstanding}

The House of Lords next revisited the issue of presumed undue influence in Etridge. ${ }^{98}$ In that case, Lord Nicholls recognized the traditional test for presumed undue influence as being a relationship of reposed trust and confidence, which included not only the status categories but also a fact-based inquiry. ${ }^{99}$ However, Lord Nicholls' test, like Lord Scarman's in Morgan, required something more. Instead of a "manifest disadvantage,” Lord Nicholls stated that the reposed trust and confidence must be coupled with a transaction that calls for explanation. ${ }^{100}$ Responding to Lord Justice Nourse's judgment in Barclays Bank Plc. v. Coleman, ${ }^{101}$ where Lord Justice Nourse questioned this requirement, Lord Nicholls reasoned that a transaction calling for explanation was necessary to avoid absurdities in the law. These absurdities would include presuming that a Christmas or birthday gift from child to parent, or a client or patient agreeing to be responsible for the reasonable fees of his legal or medical adviser, were caused by undue influence. ${ }^{102}$ Similarly, Lord Scott stated that where a Class 2 presumption was said to arise, "the nature of the impugned transaction will always be material, no matter what the relationship between the parties." 103

The "transaction that calls for explanation" requirement is only helpful if properly explained and understood. If, by that, the House of Lords meant a transaction that conferred

Ibid.

Ibid.

Supra note 2. For a comprehensive critique of the Etridge decision, see Bigwood, “Tracing,” supra note 15.

$99 \quad$ Etridge, ibid at para 10.

$100 \quad$ Ibid at para 14. See also Bigwood, "Principles and Proof," supra note 68 at 445 . Bigwood writes that this was a welcome corrective to Lord Browne-Wilkinson's adoption in Pitt of the formulation of Class 2 undue influence in Aboody, as it is the transaction that takes place within the context of the parties' special relationship that arouses suspicion of undue influence and not the special relationship itself. However, because fiduciary law dictates that any transaction between the parties that gives rise to a benefit to the trusted party (which almost any transaction will) gives rise to the presumption, I see the "transaction that calls for explanation" requirement as problematic. Certainly, Bigwood is correct in that it is the transaction in the context of the special relationship which is what gives rise to the presumption, but I feel that an emphasis on the transaction obscures the rule that the most minimal of benefits to the trusted party triggers the presumption. (1999), [2001] QB 20.

Etridge, supra note 2 at para 24. Lord Scott stated that "[s]ome transactions will be obviously innocuous and innocent. A moderate gift as a Christmas or birthday present would be an example. A solicitor who is appointed by a client as his executor and given a legacy of a moderate amount if he consents to act, is not put to proof of the absence of undue influence before he can take the legacy" (ibid at para 156). Ibid. 
a benefit on the trusted party, then that is acceptable. It is clear that no liability can attach without it. Reposed trust and confidence (deferential trust) only give rise to fiduciary accountability. Fiduciary liability comes about automatically when the trusted party is in a position of unauthorized conflict or benefit. If, however, the House of Lord's comments were meant to provide for an investigation into the "fairness" of the transaction or the trusted party's motivations, then that is problematic.

In support of the requirement of a "transaction that calls for explanation," much was made of the examples of the child's moderate Christmas gift to a parent or the client's small gift to a trusted adviser (for example, a solicitor or physician). ${ }^{104}$ However, I fail to see the force of these examples. The argument appears to rest on one, or both, of the following propositions: either, 1) there is some sort of de minimus threshold that should render the gift unimpeachable, or 2) the fact that the trusted and trusting parties are close (that is, either familial or social), and, therefore, gifts are expected or at least understandable, should negate the presumption. However, both potential arguments lack merit. First, there is no principled reason to exclude cases of small or moderate gifts. What constitutes a "moderate" gift, as opposed to a more significant one, is an arbitrary distinction with no clear demarcation point. As such, there is no satisfactory justification for excluding moderate gifts from undue influence. Second, it is entirely feasible for a close adviser or parent to use their influence to extract a benefit in the guise of a Christmas or birthday gift. To exclude such situations, $a b$ initio, is unwarranted.

This is not to say that the courts should never take the size of the gift, the close relationship between the parties, or the fact the gift was given on a holiday into consideration. On the contrary, such information could be relevant in determining whether a trusting party acted freely in making the gift or entering into the transaction. However, it is important to realize when this information is relevant. It should only be taken into consideration after the presumption has been raised by establishing: (i) deferential trust, and (ii) a transaction that benefits the trusted party. Only then can this information be used by the trusted party (defendant) in support of rebutting the presumption. This point is almost entirely academic since the cost (both in money and time) to a claimant to pursue a lawsuit for recovery of a moderate gift would certainly be prohibitive for most. Yet, it is important to show the "transaction that calls for explanation" requirement is unnecessary to erect the presumption. This reinforces the fiduciary nature of presumed undue influence.

Each significant judgment in Etridge recognizes the Class 2A status categories: "English law has identified certain relationships where the conclusion can prima facie be drawn so easily as to establish a presumption of undue influence.”105 Lord Nicholls stated that the law had adopted "a sternly protective attitude towards certain types of relationship[s] in which one party acquires influence over another who is vulnerable and dependent." ${ }^{106}$ He gave the fees of his legal or medical adviser could undone by a presumption of undue influence is unfounded. The agreement setting out who is responsible for fees would surely be entered into when the parties are both acting as principals before the limited access has occurred. This agreement would not be subject to the charge of undue influence as the relationship of influence would not have yet commenced. Etridge, supra note 2 at para 93, Lord Clyde.

Ibid at para 18. 
traditional examples of parent/child, guardian/ward, trustee/beneficiary, and solicitor/client. Lord Hobhouse explicitly recognized that these were fiduciary or analogous categories. ${ }^{107}$

However, the House of Lords retreated from Lord Browne-Wilkinson's Class 1/Class 2 analysis in O'Brien. Lord Clyde rejected the distinction between actual and presumed undue influence as illogical. ${ }^{108} \mathrm{He}$ also took issue with the further subdivision of presumed undue influence into Class 2A (status categories) and Class 2B (fact-based), stating that these further classifications "add mystery rather than illumination." ${ }^{109}$ Similarly, Lord Scott found the Class 2B classification to be of doubtful utility. ${ }^{110}$ The House of Lords emphasized a confusion in the case law since $O^{\prime}$ Brien and sought to set it on the right track. For Lord Clyde, this meant, more or less, eliminating the doctrine of presumed undue influence as it was understood:

At the end of the day, after trial, there will either be proof of undue influence or that proof will fail and it will be found that there was no undue influence. In the former case, whatever the relationship of the parties and however the influence was exerted, there will be found to have been an actual case of undue influence. In the latter there will be none. ${ }^{111}$

It appears that Lords Clyde and Scott had either misunderstood or simply disregarded the underlying purpose for which the Class 2B classification stands. There is a reason that where there is an impugned transaction (that is, any transaction where the trusted party receives a benefit by transacting with the trusting party), the plaintiff need only establish a relationship of reposed trust and confidence to raise the presumption of undue influence. A latent mischief lurks in cases of deferential trust that we seek to repress through fiduciary regulation. Since presumed undue influence is the fiduciary regulation in a specific context (cases of deferential trust), the same principles apply. We are not concerned with how the trusted party was able to derive the benefit; whether there was in fact undue pressure, coercion, or duress for Class 2 cases is irrelevant. The only fact that matters is whether the trusting party freely consented to the trusted party's conflict or benefit.

There may be another explanation for the desire to eliminate the Class 2 analysis. It may be that the law lords had recognized that presumed undue influence was actually a manifestation of the fiduciary doctrine that had separate conceptual underpinnings from actual undue influence. The law lords, therefore, wished to provide analytical clarity to the undue influence doctrine by separating it into its constituent doctrinal parts, thus ridding deferential trust of the "undue influence" label altogether. The problem with such an inference, however, is that although there was superficial recognition of the Class 2A cases as being fiduciary, there was no explicit or implicit recognition of the fiduciary nature of the Class 2 cases generally. One commentator speculates that the failure of the House of Lords to recognize the fiduciary rationale of the Class 2 cases "stems from its failure critically to 
analyze and conceptualise this area of law."112 Certainly, the lack of explication as to why presumed undue influence should be eliminated supports this conclusion.

Shortly after Etridge, the English Court of Appeal decided Hammond v. Osborn. ${ }^{113}$ Hammond dealt with the classic case of a "generous gift between persons bound by a relationship of trust and confidence." ${ }^{\text {"114 }}$ Sir Martin Nourse confidently asserted that "[t]he doctrine of presumed undue influence is now very well settled and ought to be well understood.”115 However, after Etridge, "it is apparent that neither declaration is correct."116

\section{Sir Martin Nourse found that even if the defendant's conduct was}

unimpeachable and that there was nothing sinister in it, that would be no answer to an application of the presumption. As Cotton LJ said in Allcard v Skinner ... the court does not interfere on the ground that any wrongful act has in fact been committed by the donee but on the ground of public policy, which requires it to be affirmatively established that the donor's trust and confidence in the donee has not been betrayed or abused. $^{117}$

Lord Justice Ward also found it clear that "the absence of an actual exercise of power or influence over the donor by the donee does not amount to rebuttal." ${ }^{118}$ Here, the Court of Appeal was describing and applying the conventional position. This is in direct conflict to the Etridge decision. Lord Nicholls stated that a plaintiff only succeeds by the presumption "because he has succeeded in establishing a case of undue influence." ${ }^{119}$ Similarly, Lord Clyde opined that "[a]t the end of the day ... there will either be proof of undue influence or that proof will fail." " As Scott has noted, "[t] he logical implication of [the Etridge] analysis of presumed undue influence is that, once raised, a presumption will be rebutted on a finding that no abuse of influence, improper conduct or unacceptable means of persuasion was used in order to procure the transaction."121

I submit that the Etridge decision is simply unsustainable. Thus, it is no surprise that the Court in Hammond deviated from Etridge, as it runs contrary to centuries of presumed undue influence jurisprudence. Moreover, the treatment of presumed undue influence was not grounded in fiduciary principles. The Hammond decision was correct in that it required the defendant to rebut the presumption by showing that the donor freely entered into the transaction. This is the fiduciary obligation which was entirely missed by the House of Lords in Etridge.

Bigwood, “ Principles and Proof,” supra note 68 at 443, n 45.

[2002] EWCA Civ 885 (available on QL) [Hammond].

Scott, supra note 88 at 145.

Hammond, supra note 113 at para 24.

Scott, supra note 88 at 145.

Hammond, supra note 113 at para 32 [emphasis added].

Ibid at para 45.

Etridge, supra note 2 at para 16.

Ibid at para 93.

Scott, supra note 88 at 147. 


\section{ACADEMic COMMENTARY}

\section{A. ACAdEMic Treatment of The Fiduciary Connection}

Finn has observed that presumed undue influence "has become bound to fiduciary obligation.”122 In 1989, Finn expressed that relations of influence were taking their rightful place as part of fiduciary law. ${ }^{123}$ Similarly, Anthony Duggan writes that in relationships of influence, fiduciary capacity operates as, or is analogous to, the doctrine of capacity in contract law, in that the underlying concern is to monitor transactions between trusting and trusted parties. $^{124}$

Patrick Parkinson writes that describing relations of undue influence as "fiduciary relationships of influence" is helpful, in that it highlights the underlying purpose of preventing abuse of positions of trust. ${ }^{125}$ However, he warns, "[t]he fact that a person is among the categories of people subject to the doctrine of undue influence does not mean that he or she is a fiduciary for all intents and purposes.... [T] categories which give rise to a presumption of undue influence but which are not established categories of general fiduciary obligation." ${ }^{\text {226 }}$ Parkinson’s statements appear to reflect an appreciation of the interaction between the doctrines. His comments are well received, provided that when he distinguishes presumed undue influence and fiduciary obligation generally, he is actually distinguishing between deferential trust and vigilant trust. This is why, as Duggan notes, "while it may be plausible to suggest that all relationships of influence are fiduciary relationships, the converse does not necessarily follow." 127 A person in whom deferential trust is reposed is a fiduciary, but not, perhaps, in the more common and noticeable way of understanding fiduciaries (that is, instances of vigilant trust). Instances of vigilant trust are perceived as obviously fiduciary because they generally involve the fiduciary having access to a physical (or financial) asset or confidential information. Access to these assets is easier to comprehend as giving rise to a fiduciary obligation. However, upon reflection, it should be plain to see why a trusted party having access to deferential trust, which is a type of asset as it corresponds to an individual's decision-making faculty and can be exploited for gain, requires the same protection from opportunism. It is important to reiterate that instances of both deferential trust and vigilant trust are identical in that they thwart opportunistic conduct in limited access arrangements. Instances of deferential trust may appear conceptually different from vigilant trust; but, properly understood, both concepts are aimed at the same opportunism mischief and wholly comprise the doctrine of fiduciary obligation.

PD Finn, Fiduciary Obligations (Sydney: Law Book Co, 1977) at para 173.

Finn, "Fiduciary Principle," supra note 29 at 43-44.

See Anthony Duggan, "Fiduciary Obligations in the Supreme Court of Canada: A Retrospective” (2011) 50 Can Bus LJ 453; Anthony Duggan, "Contracts, Fiduciaries and the Primacy of the Deal" in Elise Bant \& Matthew Harding, eds, Exploring Private Law (Cambridge: Cambridge University Press, 2010) 275.

Patrick Parkinson, “Fiduciary Obligations” in Patrick Parkinson, ed, The Principles of Equity, 2d ed (Sydney: Lawbook Co, 2003) 339 at 351.

Ibid.

Anthony J Duggan, “Undue Influence” in Parkinson, The Principles of Equity, ibid, 393 at 406 [footnote omitted]. 
Parkinson further states that "[i]t is not a necessary feature of all fiduciary relations that the beneficiary reposes trust and confidence in the fiduciary, and nor is it a sufficient reason for the imposition of fiduciary obligations." 128 The first half of this sentence is accurate, based on the vigilant trust/deferential trust analysis already discussed. However, I must take issue with the latter half of the sentence. Reposed trust and confidence (that is, influence) may not be necessary, but, for reasons that should be obvious by now, it certainly is a sufficient condition for the imposition of fiduciary principles. The fiduciary and undue influence doctrines perform exactly the same function where the trusted party is in a position of influence over the trusting party because of limited access. ${ }^{129}$

Glover has noted equity's jealous protection of a trusting party from the misuse of influence by a trusted party. ${ }^{130}$ He refers to these relations as "fiduciary relationships of influence" and has recognized that undue influence is another name for the doctrine. ${ }^{131}$ However, Glover also writes that " $\mathrm{t}]$ he fiduciary types of trust and confidence, influence and confidentiality each refer to distinct bodies of equitable doctrine. Each doctrine has its own functions and objectives. Separate modes of reasoning to the existence of the relations have developed accordingly. It is an error not to discriminate between them."132 He continues: "Fiduciary relations of influence have a much less exalted function.... Concern for establishing the 'undueness' of influence is with the stronger party's conscience-a much more limited horizon than the fiduciary relation of trust and confidence." 133 This is most certainly incorrect. For centuries, courts have used the language of "trust and confidence" to describe relationships of influence. ${ }^{134}$ It is also untrue that each "doctrine” has its own functions and objectives, or that somehow relations of influence are "less exalted.” They are all different descriptions of the same fiduciary doctrine: the regulation of opportunistic conduct in limited access arrangements.

Glover describes relations of influence as displaying “fiduciary characteristics.” ${ }^{\text {" He also }}$ seems to appreciate the difference between deferential and vigilant trust. He notes that while relations of influence "confer the indicia of authority or influence on one party over another"136 (deferential trust), it has a different fiduciary quality than employees, for example, who are undoubtedly fiduciaries but cannot be said to be in a position of influence (vigilant trust). ${ }^{137}$

\section{B. AdDressing Arguments Against the Fiduciary CONCEPTION}

Matthew Conaglen has rejected the synthesis of presumed undue influence and fiduciary law. ${ }^{138}$ Conaglen came to the "tentative" conclusion that " $[\mathrm{w}]$ hen they are compared

\footnotetext{
128 Parkinson, "Fiduciary Obligations," supra note 125 at 385.

129 Duggan, "Undue Influence," supra note 127 at 430-31.

130 John Glover, Commercial Equity: Fiduciary Relationships (Sydney: Butterworths, 1995) at para 1.13. Ibid.

Ibid at para 1.19 [emphasis in original].

Ibid at para 1.20 [emphasis in original].

Though, admittedly, the same language was sometimes used to describe fiduciary arrangements generally.

Glover, supra note 130 at para 8.6.

Ibid.

Ibid.

Matthew Conaglen, Fiduciary Loyalty: Protecting the Due Performance of Non-Fiduciary Duties
} (Oxford: Hart Publishing, 2010). 
carefully, the doctrines of undue influence and breach of confidence can be seen to perform functions quite different from that served by fiduciary doctrine's concept of 'loyalty." "' ${ }^{139} \mathrm{He}$ acknowledges the considerable overlap in situations where fiduciary duties and undue influence arise. ${ }^{140}$ Though, he argues, there are good reasons not to accept Rick Bigwood's formulation that presumed undue influence is an instantiation of fiduciary principles. ${ }^{141}$

First, Conaglen submits, despite the fact that there was considerable overlap in situations where the two doctrines were applied, the degree of overlap is less than it initially appears. In support of this submission, he cites Lord Scarman's assertion in Morgan that "there are plenty of confidential relationships which do not give rise to the presumption of undue influence ... and there are plenty of non-confidential relationships in which one person relies upon the advice of another." ${ }^{142}$ Unlike Lord Scarman, Conaglen sought to provide examples. He writes that company directors owe fiduciary duties, but that they are not presumed to have influence over the conduct of their companies. ${ }^{143}$ Additionally, trustees clearly owe fiduciary duties to beneficiaries, but it is not clear that they are presumed to have influence over them. ${ }^{144}$ He concludes this point: “One would have expected that a 'fiduciary' doctrine would apply without any doubt to the paradigm class of fiduciary actors.”145

It appears that Conaglen does not appreciate the way in which fiduciary law corresponds to presumed undue influence. Bigwood's (and my) argument is not that presumed undue influence and fiduciary accountability are one and the same. As I have already explained, only instances of deferential trust give rise to presumed undue influence. Cases of vigilant trust will not trigger the presumption. Thus, not all fiduciaries can be characterized as "trusted parties" in the undue influence sense. This explains why company directors and trustees can be fiduciaries, but may not be susceptible to the charge of presumed undue influence. Further, this is why, in Smith v. Kay, ${ }^{146}$ Lord Cranworth stated that " [i]t is only a particular sort of trusteeship that gives the influence."

Next, Conaglen argues that undue influence can arise where fiduciary duties are not owed. ${ }^{147}$ The example he provides is when a lawyer's retainer comes to an end; the lawyer is no longer bound by fiduciary duties, but influence may remain which renders undue influence still applicable. ${ }^{48}$ However, this example does nothing to support Conaglen's argument. There is no reason why a lawyer whose retainer has ended is not still a fiduciary. The lawyer would still likely possess the client's confidential information and this itself renders the lawyer a fiduciary. Just because there is a technicality of the retainer ending, this does not permit the lawyer to exploit his former client's confidential information for a profit without fiduciary repercussions. Additionally, if there is influence, then there is deferential trust which also makes the lawyer a fiduciary. Conaglen may be correct in saying the undue influence does not apply particularly to fiduciaries, but only if he is referring to actual undue

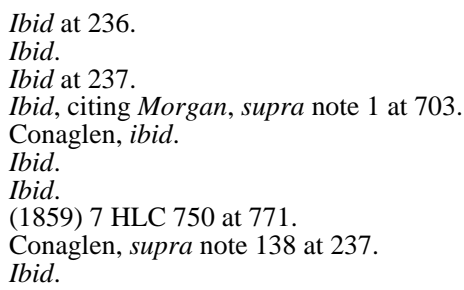


influence. Presumed undue influence cannot arise where fiduciary duties are not owed because an arrangement of reposed trust and confidence (deferential trust) necessarily means the imposition of the fiduciary obligation.

The problem with Conaglen's analysis is he relies heavily on Etridge, which, as I have shown, is a confused account of judicial reasoning. ${ }^{149}$ Conaglen rightly points out that the approach taken in Etridge, that the claimant must not only show a relationship of influence, but also "that the transaction is not readily explicable by the relationship of the parties"150 is "in stark contrast to the approach under fiduciary doctrine." 151 The "fiduciary doctrine is not concerned with the question [of] whether a fiduciary has acted in a morally reprehensible manner. The moral acceptability of a fiduciary's conduct is not a relevant consideration when a claim is brought for breach of fiduciary duty because fiduciary doctrine provides a prophylactic protection." "152 However, the "stark contrast" between the two doctrines disappears once the Etridge reasoning is discarded. Perhaps if Conaglen had relied on the conventional understanding of undue influence, he would have appreciated the fiduciary basis of presumed undue influence.

Peter Birks and Chin Nyuk Yin also expressed apprehension towards linking fiduciary law with undue influence. ${ }^{153}$ They declare that "[i]t is less useful, even dangerous, to create a close relationship between undue influence and breach of fiduciary duty."154 Moreover, they argue:

[I]t is superfluous to characterize the relationship in which one is unduly dependent on another as fiduciary. The undue dependence being sufficient in itself to explain the relief, the intrusion of a complex term such as ‘fiduciary' can only confuse.... When [fiduciary doctrine and undue influence] come to be considered directly and in detail, the most important thing to remember will be that undue influence and breach of fiduciary duty are different grounds for relief, with different consequences. It is again a matter of alternative analyses. Just as undue influence and unconscionable behaviour must be kept analytically distinct, so breach of fiduciary obligation must be distinguished from both. ${ }^{155}$

This passage likely reflects a misunderstanding of both undue influence and fiduciary law. As Chen-Wishart argues, “[f]ar from being 'superfluous' and ‘confusing', [fiduciary law] may inform the substantive and procedural limits imposed by undue influence ... on the defendant's dealing with the claimant." ${ }^{\text {"156 }}$ Duggan writes that, contrary to Birks and Yin's view, the preferred approach "would be for the merger of actual undue influence with unconscientious dealing and presumed undue influence with fiduciary law.”157

What should be clear by now is that one cannot really speak coherently about "undue influence" without qualifying whether they are referring to actual undue influence or

It appears that Conaglen mainly bases his understanding of undue influence on Etridge: ibid at 238-39. Ibid at 238, citing Etridge, supra note 2 at 798.

Conaglen, ibid.

Ibid at 239.

See Peter Birks \& Chin Nyuk Yin, "On the Nature of Undue Influence” in Jack Beatson \& Daniel Friedmann, eds, Good Faith and Fault in Contract Law (Oxford: Clarendon Press, 1995) 57.

Ibid at 91.

Ibid at 91-92.

Chen-Wishart, "Impaired Consent,"supra note 39 at 220 [footnote omitted].

Duggan, "Undue Influence," supra note 127 at 428 [emphasis added]. 
presumed undue influence. It most certainly is not useful, and is perhaps even dangerous, to link anything to "undue influence" generally. However, there is no basis for asserting that appealing to fiduciary principles is unnecessary or incorrect when discussing presumed undue influence. Perhaps it is understandable why Birks and Chin would prefer to leave fiduciary law out of the analysis, as it has a long and twisted (and recently confused) journey in the jurisprudence. Although, properly understood, the fiduciary explanation is the only coherent framework to explain presumed undue influence.

\section{THE APPROpRIATE TeST}

So where does the foregoing survey leave us? At least three significant problems are apparent. First, although there is recognition that fiduciary law plays some role in presumed undue influence, exactly what that connection is has not often been adequately articulated. A second problem arises because courts do not recognize that there are two separate doctrines at play. As such, judges have found it impossible or impractical to define the boundaries of undue influence. This is not a surprising outcome, considering any attempt to reconcile or merge the doctrines will be impossible as they are aimed at different mischief. This leads to the third observation, which is that there is no agreed-upon test to identify "special” relationships giving rise to a presumption of undue influence.

What, then, should the test be for cases of deferential trust? If the test for fiduciary accountability is limited access, should that not also be the test for deferential trust? As was discussed above, limited access is the test, but there is difficulty is discerning when "access" to the decision-making faculties (asset) of the trusting party has been acquired.

In Etridge, Lord Nicholls used the traditional language of "trust and confidence" in his analysis, but noted that many different legal tests had been offered to identify deferential trust: "Several expressions have been used in an endeavour to encapsulate the essence: trust and confidence, reliance, dependence or vulnerability on the one hand and ascendancy, domination or control on the other... None is all embracing. Each has its proper place.”158 The difficulty with this statement is that it does nothing to pin down the essence of undue influence, instead offering a smorgasbord of terms and declaring them all potentially applicable which is analytically unhelpful. Moreover:

[N]one of the labels in this area are meaningful tout court. They must always be supplemented by explanation (against the particular facts) to show that we are talking about 'trust and confidence', 'reliance', 'vulnerability', 'ascendancy', 'domination', 'control', etc, in the relevant sense - as importing 'some quality beyond that inherent in the confidence that can well exist between trustworthy persons who in business affairs deal with each other at arm's length'.,159

Instead, Bigwood suggests that once a Class 2A relation is presumed or a Class 2B relation is found on the facts, the trusted party's ability to influence the trusting party will, in itself, constitute a fiduciary relationship. ${ }^{160}$ There appears to be judicial support for a test 
of "influence." In Goldsworthy v. Brickell, ${ }^{161}$ the Court of Appeal sought to clarify the Morgan decision, where Lord Scarman stated the relevant test was a dominating influence over the trusted party. Upon reviewing earlier cases, Lord Justice Nourse stated that:

Everything which [the previous cases] said is consistent with the notion that it is enough to show that the party in whom the trust and confidence is reposed is in a position to exert influence over him who reposes it. The improbability of there being any other standard is emphasised by a consideration of some of the well defined relationships, for example, doctor and patient or solicitor and client. The reason why the presumption applies to those relationships is that doctors and solicitors are trusted and confided in by their patients and clients to give them conscientious and disinterested advice on matters which profoundly affect, in the one case their physical and mental, and in the other their material, well-being. It is natural to presume that out of that trust and confidence grows influence. ${ }^{162}$

\section{Lord Justice Parker agreed with this sentiment stating:}

[Lord Scarman] used the [dominating influence] expression as no more than a convenient means of describing a relationship in which one party is in a position to exercise influence over the other and that other naturally relies upon the first party for advice or places such trust and confidence in him that the court considers it necessary that a transaction between them...should be shown not to have been the result of the influence of the one and the reliance, trust or confidence of the other. ${ }^{163}$

The Goldsworthy decision is clear: to establish a "special” relationship, it is enough if the trust gives rise to influence. ${ }^{164}$ That is, the "ordinary and unqualified ability to 'influence' will alone constitute the relationship a fiduciary one.”165

If the influence test is to be adopted, it must be shown that it is congruent with the fiduciary framework. The overarching public policy is regulation of production opportunism. Under that public policy, the test of limited access is used to create the boundaries of fiduciary accountability. The limited access test can be broken down into its constituent parts which are: (1) access to an asset of the beneficiary, and (2) for the limited and defined purpose of acting in the beneficiary's interest. Part one of the test is the difficult question in cases of deferential trust. At what point does the trusted party acquire access to the deferential trust of the trusting party? A person's trust is an abstract, existential notion. The result is that it is difficult, if not impossible, to directly determine when the trusted party has gained access to the trusting party's deferential trust (that is, their decision-making faculties). There is, however, an indirect method of testing by proxy. This indirect method is the ability to influence.

It is important to be clear on exactly what is meant by “influence.” As Bigwood explains:

As an abstract concept, 'influence' is interchangeable simply with the notion of 'power', or even of ‘ascendancy'. I ‘influence’ you by exercising 'power’ or 'ascendancy’ over you whenever, for example, I

\footnotetext{
161 (1986), [1987] Ch 378 (CA) [Goldsworthy].

$162 \quad$ Ibid at 404 [emphasis added].

163 Ibid at 416 [emphasis added].

$164 \quad$ Flannigan, “Obligation,” supra note 4 at 303. 
'coerce', 'mislead', ‘exploit', ‘manipulate', or 'persuade’ you. On this view, there is nothing to distinguish undue influence intellectually (or practically) from any other exculpatory category that regulates abuse of interpersonal power in consensual transactional encounters. Such a distinction would be superfluous. ${ }^{166}$

However, he continues:

On the contrary, 'influence' in the undue influence formulation has a highly particularized meaning. It is different in kind from the 'influence' or 'power' that tends to concern [the doctrines of unconscionable dealing and duress]. It means fiduciary influence, and fiduciary influence may be exercised in a variety of ways: knowingly but in good faith, recklessly, coercively, deceitfully, etc. But the particular manner in which fiduciary influence is exercised in the undue influence situation is superfluous to the law's justifying exculpation from a transaction caused by the exercise of such influence.... For regardless of how fiduciary influence is exercised by D (for example, pressure, flattery, advice, argument, pleading, intercession, nondisclosure, and the like), the fact that such influence is successfully employed at all in a manner inconsistent with the defined and limited purposes of $\mathrm{P}$ and D's special relation affords a sufficient exculpatory reason ... to reverse the impugned transaction as against $\mathrm{D}$, the conflictual wrongdoer. ${ }^{167}$

My submission is that we can detect reposed trust and confidence (deferential trust) by observing the (fiduciary) ability to influence. Fiduciary influence connotes access to the trusted party's decision-making faculties. Thus, it can be said that fiduciary influence is also limited influence (limited access); that is, the influence, or access to decision-making faculties, is acquired for the limited purpose of acting in the trusting party's interest. Viewed in this light, fiduciary influence is a necessary symptom of deferential trust. Like the physician, we identify the symptom (fiduciary influence) so we can make a diagnosis (deferential trust). Therefore, properly understood, fiduciary influence is a useful proxy for trust reposed. Once reposed trust (in other words, limited access) is established, the second step in the analysis is to determine whether the trusted party is in a conflict position or received a benefit by transacting with the trusting party. An affirmative answer to either question results in the rebuttable presumption of undue influence (in other words, fiduciary liability).

It appears that in Geffen, the Supreme Court of Canada may have inadvertently endorsed "influence" as the appropriate test. Justice Wilson stated that she preferred dominance as the test, but then equated dominance with influence. She stated that "when one speaks of 'influence' one is really referring to the ability of one person to dominate the will of another," 168 and the ability "[t]o dominate the will of another simply means to exercise a persuasive influence over him or her."169 This penchant for dominance as the operative criterion is likely explained by a conflation of the underlying principles behind actual and presumed undue influence. When one realizes that presumed undue influence is actually an instance of the fiduciary obligation, which is solely concerned with production opportunism, the cognitive dissonance disappears and the dominance requirement must be abandoned. 
Dominance is too narrow. Consider the situation of a sophisticated and well-resourced corporate client that seeks legal advice from a sole practitioner whose annual income is largely dependent on fees from this client. Certainly there is deferential trust that gives rise to a fiduciary obligation. However, it would be inappropriate to describe the relationship as one where the lawyer can dominate the will of the corporate client. If domination is present in such a relationship, it is likely the other way around.

Another reason dominance is problematic is that it leads inexorably to assessments of power-dependency. Power-dependency is irrelevant in the fiduciary analysis. Justice Cromwell rightly held in Galambos v. Perez ${ }^{170}$ that "not all power-dependency relationships are fiduciary in nature, and identifying a power-dependency relationship does not, on its own, materially assist in deciding whether the relationship is fiduciary or not." This was a welcome development in Canadian fiduciary law, which has been mired in confusion for some time. ${ }^{171}$

Dominance may be a relevant consideration in Class 1 undue influence, which tends to overlap with concepts such as duress and unconscionability. However, it has no place in presumed undue influence. Justice Wilson's insistence on it may be explainable as an attempt to reconcile Class 1 (actual) and Class 2 (presumed) undue influence. Yet, viewed through the correct doctrinal lens, it is clear that dominance has no place in the Class 2 analysis.

\section{CONCLUSION}

Fiduciary influence is the appropriate test for deferential trust. Its soundness is evident by its congruence with the limited access abstraction. The (fiduciary) ability to influence connotes access to a person's decision-making faculties which can be exploited for gain. Fiduciary influence is preferred over other proxies such as "reliance," "vulnerability," "domination," and the like because the (fiduciary) ability to influence is always present when deferential trust is present and is always absent when deferential trust is absent.

What, then, are the factors that give rise to influence? As Sir Eric Sachs noted in Bundy, "[s]uch cases tend to arise where someone relies on the guidance or advice of another, where the other is aware of that reliance and where the person upon whom reliance is placed obtains, or may well obtain, a benefit from the transaction or has some other interest in it being concluded.”172 However, Sir Eric qualified, "the relationships which result in such a duty must not be circumscribed by reference to defined limits ... [e]verything depends on the particular facts." 173 It appears that the importance of the facts will vary according to their context. A party's technical expertise, the duration of the relationship, the age of the parties, and other considerations all may be relevant depending on the factual situation. ${ }^{174}$ As Lord Scarman stated in Morgan, "[t]here is no substitute in this branch of the law for a 'meticulous examination of the facts.","175

\footnotetext{
1702009 SCC 48, [2009] 3 SCR 247 at para 74.

171 See Flannigan, "Fact-Based," supra note 4.

172 Bundy, supra note 44 at 510-11.

173 Ibid at 510.

$174 \quad$ Flannigan, “Obligation,” supra note 4 at 304.

$175 \quad$ Morgan, supra note 1 at 709.
} 
Therefore, there is no limit to what gives rise to influence, because the circumstances that can give rise to fiduciary influence are infinitely variable. This fact does not reflect an unacceptable imprecision on the part of the fiduciary influence test. On the contrary, it leaves room for judges to find instances of fiduciary influence wherever they occur. Courts simply need to determine whether, on the facts, the trusted party acquired influence for the limited and defined purpose of acting in the trusting party's interest at the time of the impugned transaction. An adoption of this test gives effect to the fiduciary premise on which presumed undue influence is based. 